\title{
PERFORMA PRODUKSI DOMBA YANG DIBERI COMPLETE FEED FERMENTASI BERBASIS POD KAKAO SERTA NILAI NUTRIEN TERCERNANYA SECARA IN VIVO
}

\section{PERFORMANCE OF SHEEP FED COCOA POD BASED-FERMENTED COMPLETE FEED AND ITS IN-VIVO NUTRIENTS DIGESTION}

\author{
Suci Wulandari ${ }^{1 *}$, Ali Agus $^{2}$, Mohamad Soejono ${ }^{2}$, Muhammad Nur Cahyanto ${ }^{3}$, dan Ristianto Utomo ${ }^{2}$ \\ ${ }^{1}$ Jurusan Peternakan, Politeknik Negeri Jember, Jl. Mastrip PO BOX 164, Jember \\ ${ }^{2}$ Fakultas Peternakan, Universitas Gadjah Mada, Jl. Fauna No. 3, Bulaksumur, Yogyakarta, 55281 \\ ${ }^{3}$ Fakultas Teknologi Pertanian, Universitas Gadjah Mada, Jl. Flora No. 1, Bulaksumur, Yogyakarta, 55281
}

\section{INTISARI}

Penelitian ini dimaksudkan untuk mengetahui nilai manfaat pod kakao sebagai bahan pakan complete feed ruminansia, khususnya domba. Tujuan penelitian ini adalah untuk mengevaluasi nutrien tercerna complete feed, berbahan baku utama pod kakao terfermentasi, dan mengetahui performa produksi domba. Perlakuan CF0 adalah complete feed tanpa fermentasi (kontrol), perlakuan CF1 adalah complete feed dengan penambahan pod kakao terfermentasi, dan perlakuan CF2 adalah complete feed fermentasi berbasis pod kakao. Replikasi masing-masing perlakuan sebanyak 6 ekor domba. Analisis statistik yang digunakan adalah analisis variansi pola searah dan hasil yang berbeda dilanjutkan dengan uji beda mean Duncan new Multiple Range Test. Hasil penelitian menunjukkan bahwa penambahan pod kakao terfermentasi pada complete feed maupun pakan complete feed fermentasi berbasis pod kakao tidak berpengaruh terhadap konsumsi bahan kering, protein, maupun bahan organik tercerna, serta tidak mempengaruhi pertambahan bobot badan harian dan konversi pakan. Nilai serat kasar tercerna secara in vivo terbaik terdapat pada pakan perlakuan $\mathrm{CF} 2$.

(Kata kunci: Pod kakao, Fermentasi anaerob, Inokulum mikrobia, Complete feed, Domba)

\section{ABSTRACT}

This research was intended to observe the biological value of cocoa pod as a complete feed for ruminants, especially for sheep. The aims of this study were to evaluate the digested nutrients of fermented complete feed, with cocoa pod as the main ingredient and to observe the performance of sheep. Treatment CFO was complete feed without fermentation (control), treatment CF1 was complete feed with fermented cacao pod addition, and treatment CF2 was fermented complete feed with cocoa pod as main ingredient. Each treatment consisted of six sheep. The data were stastically analysed using one way analysis of variance and continued with Duncan new Multiple Range Test for significant results. The results showed that the addition of fermented cacao pod on complete feed or fermented complete feed based on cacao pod did not affect organic matter, protein consumption, of digested organic matter, as well as daily weight gain and feed conversion ratio. The highest value of in-vivo digestion of crude fiber was in CF2.

(Keywords: Cocoa pod, Anaerobic fermentation, Microbial inoculum, Complete feed, Sheep)

\section{Pendahuluan}

Pod kakao mempunyai kandungan gizi yang cukup baik untuk digunakan sebagai bahan pakan ternak ruminansia pengganti sebagian hijauan, karena mempunyai kandungan protein kasar (PK) $8 \%$ dan total digestible nutrients (TDN) 50,8\%. Namun terdapat kendala dalam penggunaannya sebagai pakan ternak, karena bahan pakan ini mengandung senyawa anti nutrisi berupa alkaloid 3,7- dimethylxantine yang disebut dengan theobromin (Alemawor et al., 2009). Pod kakao yang diberikan secara langsung pada ternak akan menurunkan berat badan ternak, karena kandungan lignoselulosa yang tinggi menyebabkan kecernaan

\footnotetext{
* Korespondensi (corresponding author):

Telp. +62 81234612024

E-mail: suci_ndariwulan@yahoo.com

42
}

pod kakao menjadi rendah. Kandungan selulosa dan hemiselulosa pod kakao masing-masing sebesar 35\% dan 11\% (Sobamiwa, 1993).

Upaya peningkatan kualitas pod kakao dapat dilakukan baik secara fisik, kimia, biologi, atau kombinasinya. Cara yang relatif aman, aplikatif dan tidak mencemari lingkungan yaitu cara biologis dengan metode fermentasi menggunakan inokulum mikrobia.

Pada saat ini, di masyarakat sedang berkembang bahan aditif untuk complete feed berbahan baku limbah yang diolah dengan penambahan inokulum mikrobia. Para petani menggunakan inokulum tersebut untuk meningkatkan nilai nutrisi produk pakannya. Keunggulan perlakuan dengan fermentasi inokulum mikrobia 
adalah selain mudah aplikasinya, dapat digunakan untuk peningkatan nilai nutrien produk, serta dapat diawetkan untuk diberikan di musim kemarau.

Produk inokulum komersial yang beredar di pasaran sebagian besar adalah produksi luar negeri. Indonesia sangat terbuka untuk mengembangkan inokulum dengan menggunakan isolat bakteri lokal. Tingginya keanekaragaman mikroorganisme yang ada di Indonesia sangat memungkinkan untuk ditemukannya isolat potensial guna dapat dikembangkan sebagai inokulum silase. Beberapa produk lokal seperti 'Saus Burger Pakan ${ }^{\circledR 6}$ atau SBP $^{\circledR}$ dapat dipakai sebagai inokulum karena mengandung campuran mikrobia selulolitik, mikrobia asam laktat, mikrobia amilolitik, asam amino esensial, vitamin, dan mineral.

Ternak ruminansia yang saat ini cukup menarik untuk dikembangkan adalah ternak domba karena domba mempunyai nilai ekonomis yang tinggi, seperti: dapat berkembang biak dengan cepat, mudah beradaptasi pada lingkungan yang berbeda, serta kebutuhan pakan absolut per ekornya lebih rendah dibandingkan ruminansia besar. Di samping itu, memelihara domba memerlukan biaya yang sangat minimal termasuk kemampuannya memanfaatkan sisa tanaman sebagai pakan, selalu tersedia pasarnya dan dapat menghasilkan uang tunai pada saat dibutuhkan (Soedjana, 2005; Budisatria, 2006).

Atas dasar tersebut maka untuk meningkatkan nilai manfaat pod kakao sebagai salah satu bahan pakan ruminansia perlu dikaji pengaruh pemberian pod kakao sebagai bahan utama complete feed, baik yang tidak difermentasi maupun yang difermentasi. Evaluasi terhadap nilai nutrien tercernanya (bahan organik tercerna dan serat kasar tercerna) serta pengaruhnya terhadap performa produksi ternak ruminansia perlu pula dikaji.

\section{Materi dan Metode}

\section{Materi}

Bahan yang digunakan pada penelitian ini terdiri dari domba jantan lokal yang baru tumbuh (sekitar 8 bulan sampai 1 tahun dengan kisaran berat badan 18 sampai $23 \mathrm{~kg}$ ), pakan complete feed yang bersumber dari beberapa jenis bahan pakan yaitu rumput gajah (Pennisetum purpureum), dan pod kakao sebagai sumber serat. Bekatul, polard, bungkil kedelai, dan premix sebagai bahan penyusun konsentrat, serta ditambahkan tetes dan inokulum mikrobia $\mathrm{SBP}^{\circledR}$ produksi $\mathrm{CV}$. Agro Indo Utama, Yogyakarta.

\section{Metode}

Persiapan. Sejumlah 18 ekor domba jantan dikelompokkan secara acak menjadi 3 kelompok perlakuan, 6 ekor untuk perlakuan $\mathrm{CF} 0,6$ ekor untuk perlakuan CF1, dan 6 ekor untuk perlakuan CF2. Dalam tahap persiapan ini dilakukan pembersihan kandang, penyediaan tempat pakan dan minum, pengobatan ternak yang sakit dan pemberian obat cacing.

Pemeliharaan, koleksi, dan analisis sampel. Sebelum pengambilan data, ternak diberi waktu adaptasi selama 2 minggu, dilanjutkan pengumpulan data performa produksi dilaksanakan selama 8 minggu (56 hari). Pakan diberikan 2 kali sehari, yaitu pada pukul 08.00 dan pukul 16.00 WIB. Pakan dan air minum diberikan secara $a d$ libitum. Sisa pakan diambil dan ditimbang pada hari berikutnya. Penimbangan berat badan domba pada akhir masa adaptasi digunakan sebagai berat badan awal, selanjutnya penimbangan setiap akhir minggu sebelum diberi pakan untuk mengetahui kinetika berat badan domba. Masa koleksi ditujukan untuk mengukur kecernaan pakan yang diberikan, dan berlangsung selama 7 hari sebelum masa penelitian berakhir. Selama masa koleksi, pemberian dan sisa pakan ditimbang dan diambil sampel sebanyak 5\% untuk dikomposit berdasar jenisnya. Feses dikumpulkan setiap hari (selama 7 hari) dan diambil sebanyak 5\% dari total feses, dikomposit, dan diambil 5\% untuk analisis proksimat (AOAC, 2005).

Pakan penelitian. Penelitian ini menggunakan complete feed berbasis pod kakao. Dalam pembuatan complete feed untuk perlakuan pakan, pod kakao sebelumnya dibuat tepung terlebih dahulu dengan cara pod kakao yang telah dikeringkan selanjutnya digiling dengan diameter lubang saringan $4 \mathrm{~mm}$. Tepung pod kakao kemudian digunakan sebagai bahan pakan penyusun ransum.

Complete feed perlakuan CF0 (complete feed non fermentasi) dibuat dengan cara mencampurkan $50 \%$ pod kakao giling, 40\% konsentrat, dan $10 \%$ rumput gajah berdasarkan bahan kering (BK) lalu diaduk rata kemudian ditambah tetes $2 \%$ dan air agar complete feed mencapai kadar air $40 \%$. Complete feed perlakuan CF1, pod kakao fermentasi dibuat terlebih dahulu. Saus Burger Pakan $^{\circledR}$ sebanyak $0,05 \%$ dari berat pod kakao, diaktifkan terlebih dahulu dalam larutan tetes $2 \%$, kemudian dicampurkan dalam pod kakao dan ditambah air sampai pod kakao mencapai kadar air $40 \%$, dan diperam selama 6 hari di dalam silo (botol kecil, kapasitas $200 \mathrm{~g}$ ) dalam kondisi anaerob. Setelah 6 hari pod kakao hasil fermentasi dicampur dengan 40\% konsentrat dan 10\% rumput gajah berdasar BK. Rumput gajah dicacah dengan panjang sekitar $10 \mathrm{~cm}$. Semua komponen pakan komplit diaduk rata, kemudian dicampurkan lagi dengan tetes $2 \%$ dan air sampai complete feed 
mencapai kadar air 40\%. Pada complete feed perlakuan CF2 (complete feed fermentasi), larutan $\mathrm{SBP}^{\circledR}$ yang telah di-aktifkan dalam larutan tetes $2 \%$ selama 2 jam sebanyak $0,05 \%$ dari berat complete feed, dicampur dengan campuran pod kakao 50\%, konsentrat $40 \%$ dan rumput gajah yang dicacah sebanyak $10 \%$ berdasar BK, kemudian ditambah air sampai mencapai kadar air $40 \%$. Setelah tercampur rata, dimasukkan dalam silo (botol kecil, kapasitas $200 \mathrm{~g}$ ) sambil dimampatkan untuk mencapai kondisi anaerob, kemudian difermentasi selama 6 hari. Complete feed tersebut disusun secara iso protein dan iso TDN dengan kandungan PK sekitar 11\% dan TDN sekitar $60 \%$ (Ranjhan, 1981).

Data yang diperoleh dianalisis dengan analisis variansi pola searah menurut Steel dan Torrie (1993), kemudian jika hasilnya berbeda nyata dilanjutkan dengan uji Duncan's new Multiple Range Test. Parameter yang diamati adalah komposisi kimia complete feed meliputi: bahan kering (BK), bahan organik (BO), serat kasar (SK), dan protein kasar (PK), konsumsi bahan kering (BK), konsumsi protein kasar (PK) dan konsumsi bahan organik (BO), serta pertambahan berat badan harian per satuan waktu $(\mathrm{PBBH})$ dan feed conversion ratio (FCR).

Kecernaan dan nutrien tercerna complete feed. Evaluasi nilai nutrien tercerna dari complete feed (dengan bahan baku utama pod kakao) hasil fermentasi pada penelitian ini dilakukan secara invivo. Nutrien tercerna diperoleh dari kecernaan nutrien dikalikan dengan jumlah nutrien yang dikonsumsi. Untuk mendapatkan kecernaan nutrien pakan terlebih dahulu diukur jumlah nutrien pakan yang dikonsumsi dan jumlah nutrien pakan yang dikeluarkan (Tillman et al., 1991). Menurut Utomo (2012), perhitungan untuk penetapan in vivo suatu bahan pakan dapat ditetapkan sebagai berikut:

$\underset{(\mathrm{KN} \%)}{\text { Kecernaan nutrien }}=\frac{\mathrm{A} \times \mathrm{a}(\%)-\mathrm{B} \times \mathrm{b}(\%)}{\mathrm{A} \times \mathrm{a}(\%)} \times 100 \%$

$\mathrm{A}=$ rata-rata bahan kering yang dikonsumsi ( $\mathrm{g}$ )

$\mathrm{B}=$ rata-rata bahan kering feses yang dikeluarkan (g)

$\mathrm{a}=$ kadar nutrien dalam pakan A (\%)

$\mathrm{b}=$ kadar nutrien dalam feses B (\%)

Nutrien tercerna $(\%)=\mathrm{KN} \% \quad \mathrm{x}$ nutrien dalam pakan (\%)

Parameter kecernaan yang diamati adalah kecernaan bahan organik (KcBO), bahan organik tercerna (BOT), kecernaan serat kasar dan serat kasar tercerna (SKT).
Performa produksi ternak domba. Parameter ini bertujuan untuk mengevaluasi performa produksi serta aseptabilitas domba terhadap produk pod kakao dalam pakan complete feed (berbahan baku utama pod kakao) baik yang tanpa maupun dengan fermentasi.

Konsumsi bahan kering (BK). Konsumsi BK dihitung dengan cara mengurangi jumlah BK pakan yang diberikan dengan sisa pakan dikalikan dengan bahan keringnya (\%). Rataan konsumsi pakan diperoleh dari total konsumsi selama perlakuan (56 hari).

Konsumsi protein kasar (PK) dan bahan organik tercerna (BOT). Konsumsi PK dihitung dengan cara konsumsi BK pakan dikalikan kadar PK pakan. Konsumsi BOT dihitung dengan cara konsumsi BK pakan dikalikan kadar BOT.

Pertambahan berat badan harian (PBBH). Penimbangan domba dilakukan setiap awal minggu sebelum diberi pakan pagi. Data berat badan setiap minggu digunakan untuk membuat grafik pertumbuhan berat badan sebagai sumbu y (Gambar 2), sedangkan waktu (mingguan) sebagai sumbu $\mathrm{x}$ sehingga diperoleh persamaan regresi $\mathrm{y}=\mathrm{a}+\mathrm{bx}$, dimana $b$ adalah slope yang merupakan nilai PBB mingguan. Pertambahan berat badan harian (g/ekor/hari) diperoleh dari PBB mingguan dibagi 7.

Feed conversion ratio (FCR). Feed conversion ratio atau konversi pakan diperoleh dari jumlah pakan yang dikonsumsi untuk mendapatkan $1 \mathrm{~kg}$ berat badan dan dalam waktu tertentu.

$$
\mathrm{FCR}=\frac{\text { Konsumsi BK (g/ekor/hari) }}{\mathrm{PBBH}(\mathrm{g} / \text { ekor/hari) }}
$$

\section{Hasil dan Pembahasan}

\section{Komposisi nutrien}

Komposisi nutrien complete feed berbasis pod kakao non fermentasi (perlakuan CF0), complete feed dengan bahan baku utama pod kakao fermentasi ( $\mathrm{CF} 1)$ dan complete feed fermentasi (CF2) disajikan pada Tabel 1.

Proses fermentasi secara umum menyebabkan terjadinya penurunan $\mathrm{BK} / \mathrm{BO}$ yang disebabkan oleh adanya respirasi dan fermentasi. Respirasi menyebabkan kandungan nutrien terurai sehingga menurunkan $\mathrm{BK} / \mathrm{BO}$ silase, sedangkan fermentasi menghasilkan asam laktat dan air. Perlakuan CF2 (complete feed fermentasi) dapat menekan kehilangan bahan organik karena pod kakao fermentasi yang digunakan untuk menyusun $\mathrm{CF} 1$ mempunyai $\mathrm{BK} / \mathrm{BO}$ yang lebih kecil dibanding dengan pod kakao tanpa fermentasi yang digunakan untuk menyusun CF2 pada kondisi iso protein dan iso energi. Sofyan et al. (2001) menyatakan bahwa turunnya BO selama proses fermentasi adalah 
Tabel 1. Komposisi nutrien complete feed berbasis pod kakao non fermentasi dan fermentasi (nutrient composition of complete feed based non-fermented cocoa pods and fermented), $\mathrm{n}=6$

\begin{tabular}{|c|c|c|c|c|}
\hline \multirow{2}{*}{ Komposisi (berdasar BK) (composition (DM base)) } & \multicolumn{3}{|c|}{ Perlakuan (treatment) } & \multirow{2}{*}{ SEM } \\
\hline & CF0 & CF1 & $\mathrm{CF} 2$ & \\
\hline Bahan kering (dry matter) & $65,3^{\mathrm{a}}$ & $58,9^{\mathrm{c}}$ & $63,5^{\mathrm{b}}$ & 0,70 \\
\hline Bahan organik (organic matter) & $96,4^{\mathrm{a}}$ & $95,7^{\mathrm{b}}$ & $96,8^{\mathrm{a}}$ & 0,16 \\
\hline Serat kasar (crude fiber) ${ }^{\mathrm{ns}}$ & 22,4 & 22.7 & 22,5 & 0,24 \\
\hline Protein kasar (crude protein $)^{\mathrm{ns}}$ & 12,12 & 12,4 & 12,9 & 0,41 \\
\hline
\end{tabular}

$\mathrm{CF} 0=$ complete feed berbasis pod kakao, non fermentasi (complete feed cocoa pod-based, non-fermented);

$\mathrm{CF} 1=$ complete feed dengan bahan baku utama pod kakao fermentasi (complete feed with the main raw material cocoa pod fermentation); dan CF2 = complete feed fermentasi (fermented complete feed).

a,b,c Superskrip yang berbeda pada baris yang sama menunjukkan perbedaan yang nyata $(\mathrm{P}<0,05)($ different superscript at the same row indicate significant differences $(P<0.05))$.

$\mathrm{SEM}=$ standard error of mean.

${ }^{\text {ns }}$ berbeda tidak nyata (non significant).

$\mathrm{n}=$ jumlah ulangan (number of replications).

sebagai akibat dari terombaknya beberapa zat makanan seperti karbohidrat, lemak, serta protein oleh mikroorganisme.

Pada penelitian ini, fermentasi secara anaerob belum mampu menurunkan serat kasar complete feed fermentasi dan tidak meningkatkan protein kasar complete feed dibanding complete feed tanpa fermentasi (CF0). Hal ini diduga karena tekstur bahan complete feed yang tidak seragam sehingga untuk mendapatkan kondisi yang benar-benar anaerob secara cepat kurang optimal. Penambahan inokulum bakteri dengan dosis $0,05 \%$ berdasar as fed pakan dan waktu fermentasi 6 hari belum mampu menurunkan serat kasar complete feed berbasis pod kakao yang menggunakan tetes $2 \%$. Hal ini menunjukkan bahwa inokulum bakteri yang ditambahkan pada complete feed fermentasi, terutama bakteri selulolitik, kurang bekerja dengan optimum, sedangkan bakteri asam laktat yang berkembang tidak mempunyai kemampuan dalam mendegradasi dinding sel. Kung (2001) menyatakan bahwa peningkatan kecernaan silase karena penambahan inokulum bakteri asam laktat disebabkan oleh hidrolisis partikel asam pada sebagian hemiselulosa. Kandungan protein kasar antar perlakuan pada penelitian ini tidak berbeda satu sama lain. Peningkatan kandungan protein kasar umumnya lebih disebabkan karena penurunan prosentase BK total setelah fermentasi (Tabel 1).

\section{Kecernaan dan nutrien tercerna}

Hasil penelitian menunjukkan bahwa penambahan pod kakao fermentasi pada complete feed maupun perlakuan fermentasi pada complete feed tidak mempengaruhi nilai $\mathrm{KcBO}$ dan $\mathrm{BOT}$, namun meningkatkan $(\mathrm{P}<0,05)$ nilai kecernaan serat kasar dan serat kasar tercerna. Peningkatan nilai cerna disini dipengaruhi oleh peningkatan jumlah serat kasar yang tercerna, dimana serat kasar adalah salah satu komponen dari bahan organik. Peningkatan kualitas pakan melalui teknologi fermentasi anaerob dengan menggunakan inokulum bakteri dapat menurunkan kadar serat, mengubah struktur kimia substrat dari senyawa kompleks menjadi senyawa yang lebih sederhana, serta mengeliminasi zat antinutrisi. Hal ini dikarenakan inokulum mikrobia yang ditambahkan mengandung bakteri selulolitik yang mampu mendegradasi serat. Nilai bahan organik tercerna (BOT) dan serat kasar tercerna (SKT) tersaji pada Tabel 2.

Alemawor et al. (2009) menyatakan bahwa penggunaan pod kakao sebagai pakan ternak ada batasannya karena mengandung senyawa anti nutrisi berupa alkaloid theobromin (3,7 dimethylxantine), juga oleh rendahnya kandungan nutrien, terutama dengan adanya kadar serat atau lignoselulolitik yang tinggi. Selain itu, limbah kulit buah kakao yang diberikan secara langsung pada ternak justru akan menurunkan berat badan ternak (Anonimus, 2008). Namun dalam penelitian ini menunjukkan hal yang berbeda bahwa proses pengeringan dan fermentasi dalam bentuk complete feed dengan komposisi pod kakao sampai 50\% dapat memberikan nilai BOT sebesar 50,4\% (CF0), $52,4 \% \quad$ (CF1), 52,5\% (CF2), juga terjadi peningkatan $\mathrm{PBBH}$ domba dalam g/ekor/hari ratarata 141,4 (CF0), 140,0 (CF1) dan 147,1, sedangkan menurut Ranjhan (1981) untuk ternak domba dengan berat badan sekitar $25 \mathrm{~kg}$ dengan pemberian PK sebesar $12,7 \%$ dan TDN sebesar $60 \%$ dalam ransumnya, menghasilkan pertambahan berat badan $100 \mathrm{~g} /$ hari. Hasil penelitian ini cukup baik, karena dimungkinkan bakteri selulolitik yang ditambahkan juga mempunyai kemampuan mendegradasi theobromin. 
Tabel 2. Nilai kecernaan bahan organik, bahan organik tercerna, kecernaan serat kasar dan serat kasar tercerna complete feed berbasis pod kakao (value organic matter digestibility of digested organic matter crude fiber digestibility and digested crude fibers of cocoa pod-based complete feed), $\mathrm{n}=6$

\begin{tabular}{lcccc}
\hline \hline \multirow{2}{*}{ Variabel (variable) } & \multicolumn{3}{c}{ Perlakuan (treatment) } & \multirow{2}{*}{ SEM } \\
\cline { 2 - 4 } & CF0 & CF1 & CF2 & 0,84 \\
\hline KcBO (OMD) (\%) & 52,4 & 55,6 & 54,3 & 0,81 \\
BOT (DOM) (\%) & 50,4 & 52,4 & 52,5 & 1,59 \\
KcSK (CFD) (\%) & $14,4^{\mathrm{bs}}$ & $22,1^{\mathrm{ab}}$ & $24,3^{\mathrm{a}}$ & 0,35 \\
SKT (DCF) (\%) & $3,1^{\mathrm{b}}$ & $4,5^{\mathrm{ab}}$ & $5,3^{\mathrm{a}}$ & \\
\hline
\end{tabular}

KcBO: kecernaan bahan organik (OMD: organic matter digestibility), BOT: bahan organik tercerna (DOM: digested organic matter), KcSK: kecernaan serat kasar (CFD: crude fiber digestibility), SKT: serat kasar tercerna (DCF: digested crude fibers).

$\mathrm{CF} 0=$ complete feed berbasis pod kakao, non fermentasi (complete feed cocoa pod-based, non-fermented); $\mathrm{CF} 1=$ complete feed dengan bahan baku utama pod kakao fermentasi (complete feed with the main raw material cocoa pod fermentation); dan CF $2=$ complete feed fermentasi (fermented complete feed $)$.

a,b,c Superskrip yang berbeda pada baris yang sama menunjukkan perbedaan yang nyata $(\mathrm{P}<0,05)($ different superscript at the same row indicate significant differences $(P<0.05))$.

$\mathrm{SEM}=$ standard error of mean.

${ }^{n}$ berbeda tidak nyata (non significant).

$\mathrm{n}=$ jumlah ulangan (number of replications).

Fermentasi complete feed yang berbasis pod kakao pada penelitian ini meningkatkan nilai KcSK dan SKT. Hal ini menjelaskan bahwa pengaruh pemberian inokulum mikrobia terhadap pakan complete feed memberikan respon yang baik terhadap nilai cerna serat kasar. Complete feed tanpa perlakuan fermentasi (CF0) mempunyai nilai serat kasar tercerna yang paling rendah dibandingkan $\mathrm{CF} 1$ dan $\mathrm{CF} 2$ yaitu berturut-turut sebesar 3,1\%, 4,5\% dan 5,3\%. Hal ini dikarenakan adanya aktivitas bakteri selulolitik dari inokulum mikrobia yang ditambahkan. Mekanisme aktivitas enzim selulase tersebut merupakan aktivitas enzim kompleks yang bekerja secara sinergis dari tiga tipe enzim selulase meliputi endo- $\beta$-1,4-glukanase, eksoglukanase dan $\beta$-glukosidase yang secara bertahap memotong antar molekul pada ikatan $\beta$ 1,4-glukosidik. Enzim tersebut memotong rantai selulosa menjadi unit oligosakarida, selobiosa dan glukosa (Lin et al., 2012). Tingginya nilai cerna perlakuan CF2 diduga karena inokulum mikrobia telah memfermentasi lebih banyak bahan penyusun complete feed sedangkan pada perlakuan CF1, fermentasi hanya dilakukan pada bubuk pod kakao saja sehingga nilai SKT pada CF1 lebih rendah dibanding CF2. Tillman et al. (1991) menyatakan bahwa komposisi kimia yang paling berpengaruh dalam kecernaan adalah kandungan serat kasar yang merupakan bahan penyusun dinding sel yang sukar dicerna.

\section{Performa produksi ternak domba}

Hasil penelitian menunjukkan bahwa kedua jenis perlakuan pakan tidak mempengaruhi nilai konsumsi BK, PK, dan BOT pada domba lokal (Tabel 3). Hal ini menunjukkan bahwa domba yang telah diadaptasikan pakannya dengan pod kakao tidak mengalami masalah dengan adanya pod kakao dalam pakan hingga level 50\%. Hal ini dimungkinkan bahwa pod kakao yang dikeringkan dan digiling kemudian dicampur rata dengan bahan lain membentuk complete feed, baik difermentasi maupun tidak difermentasi, cukup disukai oleh ternak domba.

Parakkasi (1999) menyatakan bahwa tinggi rendahnya konsumsi pakan dipengaruhi oleh palatabilitas. Purbowati (2011) menyatakan bahwa pakan yang cukup kandungan protein dan lebih halus ukuran strukturnya dapat meningkatkan jumlah konsumsi makanan. Pada complete feed disini pod kakao sudah tidak bisa dipisahkan dengan bahan lain karena digiling dan tercampur dengan bahan pakan lain seperti bungkil kedelai, dedak halus, dan polard, sehingga ternak tidak dapat memilih bahan pakan.

Dalam penelitian ini rata-rata persentase konsumsi BK harian terhadap domba adalah 4,7\% pada $\mathrm{CF} 0 ; 5,1 \%$ pada $\mathrm{CF} 1$ dan $5,1 \%$ pada $\mathrm{CF} 2$ dari berat badan. Konsumsi BK ini masih dalam kisaran normal. Ranjhan (1981) menyatakan bahwa konsumsi BK sekitar 3-5\% dari bobot hidup. Faktor-faktor yang mempengaruhi konsumsi pakan 
adalah ternak bersangkutan, pakan yang diberikan, dan lingkungan tempat ternak tersebut dipelihara (Parakkasi, 1999).

Kinetika konsumsi BK domba yang diberi pakan mengandung $50 \%$ pod kakao dalam ransumnya dapat dilihat pada Gambar 1. Dari grafik kinetika konsumsi pakan tersebut menunjukkan bahwa pada minggu ke-1 sampai ke-2 relatif tidak ada kenaikan konsumsi BK dari domba jantan yang sedang tumbuh, kemudian setelah itu mengalami peningkatan konsumsi BK selama pemeliharaan berlangsung. Hal ini menunjukkan bahwa konsumsi bahan kering complete feed berbasis pod kakao semakin meningkat dengan semakin lamanya waktu pemeliharaan. Hal ini dapat disebabkan oleh berat badan yang semakin meningkat, sehingga kebutuhan akan BK pun semakin meningkat. Zain (2009) menyatakan bahwa konsumsi pakan akan meningkat sejalan dengan semakin bertambah besarnya ternak.

Nilai konsumsi BOT g/ekor/hari dalam penelitian ini disetarakan dengan nilai konsumsi energi TDN, yaitu sebesar 508,8 (CF0), 560,1 (CF1) dan 555,9 (CF2). Menurut Utomo (2012), nilai TDN bahan pakan yang kandungan ekstrak eternya rendah, seperti bahan pakan berserat pada umumnya, dapat disetarakan dengan BOT. Konsumsi PK domba yang diberi perlakuan CF0, CF1, dan CF2 berturut-turut adalah 118,0, 125,2 dan 128,3 g/ekor/hari. Hasil penelitian tersebut

Tabel 3. Konsumsi bahan kering, protein kasar, dan bahan organik tercerna pada domba (dry matter intake, crude protein intake and intake of digested organic matter of sheep) $n=6$

\begin{tabular}{lcccc}
\hline \hline \multicolumn{1}{c}{ Parameter } & \multicolumn{3}{c}{ Perlakuan (treatment) } & SEM \\
\cline { 2 - 4 } & CF0 & CF1 & CF2 & \\
\hline $\begin{array}{l}\text { Konsumsi BK (g/ekor/hari) (DM intake } \\
(\mathrm{g} / \text { head/day) })^{\mathrm{ns}}\end{array}$ & 970,8 & $1.008,3$ & 993,9 & 19,24 \\
$\begin{array}{l}\text { Konsumsi PK (g/ekor/hari) (CP intake } \\
(\mathrm{g} / \text { head/day)) }\end{array}$ & 118,0 & 125,2 & 128,3 & 4,67 \\
$\begin{array}{l}\text { Konsumsi BOT (g/ekor/hari) (DOM intake } \\
(\mathrm{g} / \text { head/day)) }\end{array}$ & 508,8 & 560,1 & 555,9 & 14,91 \\
\hline
\end{tabular}

BK: bahan kering (DM: dry matter), PK: protein kasar (CP: crude protein), BOT: bahan organik tercerna (DOM: digested organic matter).

$\mathrm{CF} 0=$ complete feed berbasis pod kakao, non fermentasi (complete feed cocoa pod-based, non-fermented); $\mathrm{CF} 1=$ complete feed dengan bahan baku utama pod kakao fermentasi (complete feed with the main raw material cocoa pod fermentation); dan $\mathrm{CF} 2=$ complete feed fermentasi (fermented complete feed).

$\mathrm{SEM}=$ standard error of mean.

${ }^{n}$ berbeda tidak nyata (non significant).

$\mathrm{n}=$ jumlah ulangan (number of replications).

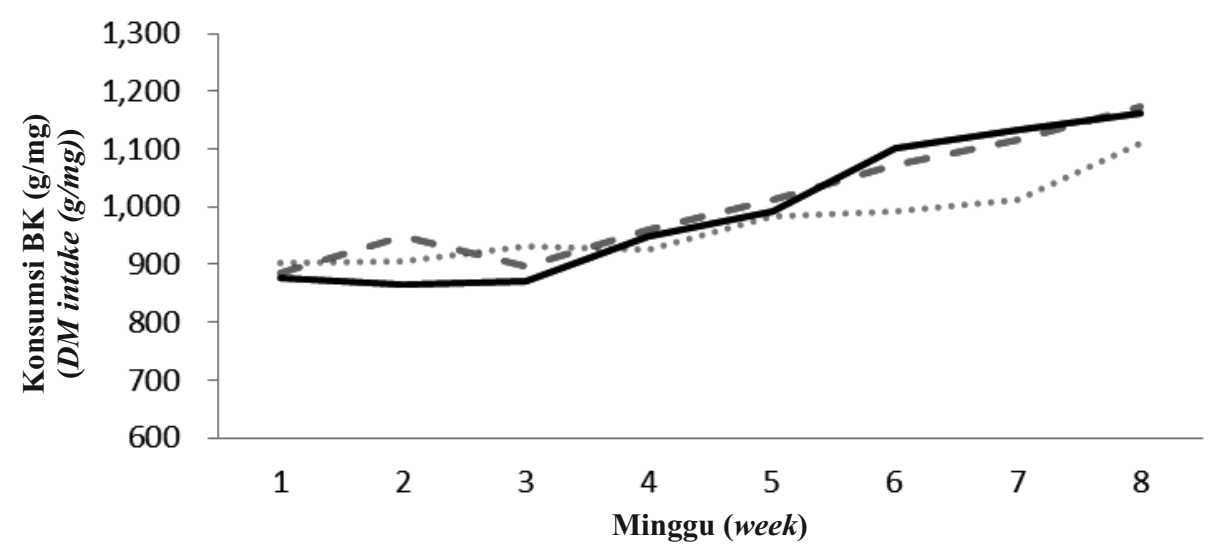

Gambar 1. Kinetika konsumsi bahan kering domba yang diberi pakan mengandung 50\% pod kakao dalam ransumnya (kinetics of dry matter intake of sheep fed containing 50\% cocoa pod in the rations).

........ $\mathrm{CF} 0=$ complete feed berbasis pod kakao, non fermentasi (complete feed cocoa pod-based, non-

fermented); - - - - CF1 = complete feed dengan bahan baku utama pod kakao fermentasi (complete feed with the main raw material cocoa pod fermentation); - $\mathrm{CF} 2=$ complete feed fermentasi (fermented complete feed). 
menunjukkan bahwa konsumsi energi dan protein domba ketiga perlakuan sudah tercukupi. Kearl (1982) menyatakan bahwa kebutuhan hidup pokok dan pertumbuhan domba dengan berat badan antara 15 sampai $25 \mathrm{~kg}$ adalah energi TDN sebesar 310 sampai $410 \mathrm{~g} / \mathrm{ekor} / \mathrm{hari}$ dan kebutuhan PK sebesar 95 sampai $122 \mathrm{~g} / \mathrm{ekor} / \mathrm{hari}$.

Pertambahan berat badan harian $(\mathrm{PBBH})$ dan konversi pakan (FCR) domba tersaji pada Tabel 4. Hasil penelitian menunjukkan bahwa kedua macam perlakuan tidak mempengaruhi PBBH domba. Hal ini diduga disebabkan karena perlakuan pakan tidak meningkatkan konsumsi BK. Parakkasi (1999) menyatakan bahwa PBBH dipengaruhi oleh konsumsi pakan domba. Semakin tinggi bahan kering yang dikonsumsi oleh domba, maka akan semakin tinggi pula pertambahan bobot hidupnya.

Pertambahan berat badan merupakan cermin kualitas pakan yang diberikan. Complete feed dengan $50 \%$ pod kakao yang difermentasi dengan inokulum mikrobia (perlakuan CF2) menghasilkan nilai SKT tertinggi (Tabel 2), namun masih belum bisa meningkatkan PBBH domba. Nilai PBBH ketiga perlakuan tersebut berturut-turut adalah 141,4 pada perlakuan CF0; 140,0 pada perlakuan CF1 dan 147,1 g/ekor/hari pada perlakuan CF2. PBBH hasil penelitian ini lebih tinggi dari hasil penelitian Zain (2009), yaitu sebesar 95,71-102,86 g/ekor/hari untuk domba yang diberi pakan pod kakao amoniasi sampai 50\%. Hal ini dimungkinkan karena perbedaan cara penyajian dan kualitas pakan. Pada penelitian Zain (2009), pemberian pod kakao amoniasi diberikan secara terpisah dengan konsentrat dan hijauan. Hal ini memberikan kesempatan bagi domba untuk memilih bahan pakan dalam mengkonsumsi pakannya, sehingga pakan yang dikonsumsi menjadi kurang efisien dengan nilai konversi pakan yang cukup tinggi antara 33,0-38,5 jika dibanding dengan nilai konversi pakan dalam penelitian ini sebesar 7,0-7,5 (Tabel 4).
Gambar grafik kinetika berat badan domba yang diberi pakan mengandung 50\% pod kakao dalam ransumnya disajikan pada Gambar 2. Dari gambar grafik berat badan domba tersebut nampak bahwa secara umum sampai minggu kedua belum nampak terjadi kenaikan berat badan. Kenaikan berat badan terjadi setelah minggu kedua pemeliharaan. Hal ini sesuai dengan grafik konsumsi BK bahwa pada awal minggu pemeliharaan konsumsi BK domba belum meningkat.

Dengan lama waktu pemeliharaan 2 bulan dan masa adaptasi 2 minggu, ternak domba dalam penelitian ini pada umumnya tidak mengalami keracunan karena theobromin. Hal ini dikarenakan pod kakao yang dikeringkan dengan menggunakan panas sinar matahari sudah dapat mengurangi kandungan theobromin, dan kandungan theobromin akan semakin banyak berkurang dengan ditambah perlakuan fermentasi (silase) menggunakan inokulum mikrobia. Proses fermentasi dalam penelitian ini dapat mempengaruhi penurunan kandungan theobromin, karena adanya penambahan bakteri selulolitik dari inokulum mikrobia yang mampu mendegradasi theobromin. Penelitian pendahuluan menunjukkan bahwa fermentasi pod kakao selama 6 hari dengan inokulum mikrobia dapat menurunkan kandungan theobromin sekitar $17,02 \%$, yaitu dari $123,88 \mathrm{ppm}$ pada awal fermentasi menjadi 102,79 ppm setelah fermentasi (Wulandari, 2013). Mazzafera (2002) menyatakan bahwa penurunan kandungan theobromin karena terjadi degradasi theobromin secara langsung dan perlahan-lahan menjadi 3-methylxanthine yang kemudian dikonversi menjadi xanthine dan masuk ke jalur degradasi ureide.

Pada perlakuan CF2, walaupun tidak berbeda nyata, cenderung menghasilkan pertambahan berat badan tertinggi (Tabel 4), dimungkinkan pula karena bakteri selulolitik dan bakteri asam laktat yang berasal dari silase dengan penambahan inokulum mikrobia, dapat menstimulir proses

Tabel 4. Pertambahan berat badan harian dan konversi pakan domba (weight gain and feed conversion ratio) $\mathrm{n}=6$

\begin{tabular}{|c|c|c|c|c|}
\hline \multirow{2}{*}{ Variabel (variable) } & \multicolumn{3}{|c|}{ Perlakuan (treatment) } & \multirow{2}{*}{ SEM } \\
\hline & CF0 & CF1 & CF2 & \\
\hline $\begin{array}{l}\text { Pertambahan berat badan harian (g/ekor/hari) (daily weight } \\
\text { gain }(\mathrm{g} / \text { head /day }))^{\mathrm{ns}}\end{array}$ & 141,4 & 140,0 & 147,1 & 9,83 \\
\hline Konversi pakan (feed conversion ratio $)^{\mathrm{ns}}$ & 7,5 & 7,7 & 7,5 & 0,62 \\
\hline \multicolumn{5}{|c|}{$\begin{array}{l}\mathrm{CF} 0=\text { complete feed berbasis pod kakao, non fermentasi (complete feed cocoa pod-based, non-fermented }) \text {; } \\
\mathrm{CF} 1=\text { complete feed dengan bahan baku utama pod kakao fermentasi (complete feed with the main raw } \\
\quad \text { material cocoa pod fermentation); dan } \mathrm{CF} 2=\text { complete feed fermentasi (fermented complete feed }) . \\
\mathrm{SEM}=\text { standard error of mean. } \\
\mathrm{n} \text { berbeda tidak nyata (non significant). } \\
\mathrm{n}=\text { jumlah ulangan (number of replications). }\end{array}$} \\
\hline
\end{tabular}




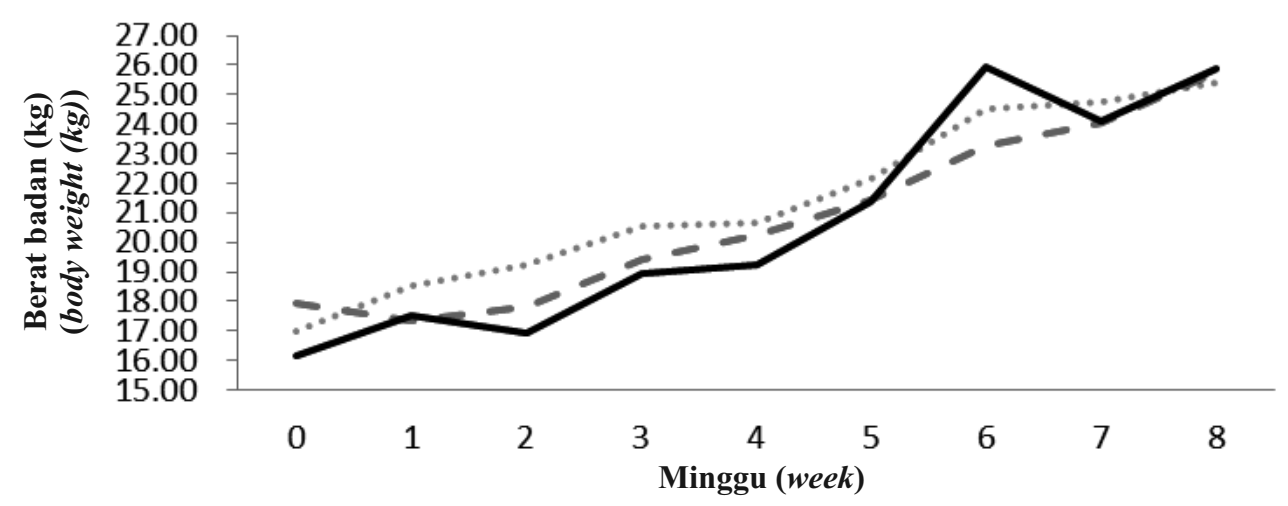

Gambar 2. Kinetika berat badan domba yang diberi pakan mengandung 50\% pod kakao dalam ransumnya (kinetics weight lambs fed containing $50 \%$ cocoa pod in the rations). $\cdots . . . \cdot \mathrm{CF} 0=$ complete feed berbasis pod kakao, non fermentasi (complete feed cocoa pod-based, non-fermented); - - - - CF1= complete feed dengan bahan baku utama pod kakao fermentasi (complete feed with the main raw material cocoa pod fermentation $) ;-\mathrm{CF} 2=$ complete feed fermentasi (fermented complete feed).

fermentasi mikrobia rumen. Hasil penelitian Ratnakomala (2006) menunjukkan bahwa inokulum bakteri asam laktat yang ditambahkan pada silase masih bertahan hidup dalam rumen ternak dan dapat meningkatkan pertambahan berat badan sapi. Hal ini dimungkinkan juga terjadi pada bakteri selulolitik silase yang dapat menstimulir proses degradasi serat dan theobromin dalam rumen.

Konversi pakan dapat digunakan untuk mengetahui efisiensi produksi karena erat kaitannya dengan biaya produksi. Semakin rendah nilai konversi pakan maka efisiensi penggunaan pakan makin tinggi. Rata-rata konversi pakan (FCR) dalam penelitian ini tersaji dalam Tabel 4. Konversi pakan antar perlakuan dalam penelitian ini tidak berbeda nyata, hal ini dikarenakan konsumsi BK dan PBBH yang dihasilkan juga tidak berbeda nyata. Rata-rata konversi pakan untuk masingmasing perlakuan yaitu 7,5 (CF0), 7,7 (CF1), dan 7,5 (CF2). Angka konversi pakan tersebut artinya untuk meningkatkan berat badan sebesar $1 \mathrm{~kg}$ dibutuhkan 7,5 kg BK pakan untuk perlakuan CF0, 7,7 kg BK pakan untuk perlakuan CF1 dan 7,5 kg BK pakan untuk perlakuan CF2. Konversi pakan yang dihasilkan dalam penelitian ini cukup baik, karena menurut Purbowati et al. (2009), konversi pakan domba di daerah tropis berkisar antara 7-15, artinya untuk menghasilkan $1 \mathrm{~kg}$ pertambahan berat badan dibutuhkan BK pakan sebanyak 7-15 kg. Nilai konversi pakan yang semakin kecil menurut Tillman et al. (1991) berarti ternak tersebut semakin efisien dalam memanfaatkan pakan. Dari berat badan dan konversi pakan yang dihasilkan, pemberian complete feed berbasis pod kakao, baik non fermentasi maupun fermentasi dapat memenuhi kebutuhan hidup dan produksi domba.

\section{Kesimpulan}

Dari penelitian ini dapat disimpulkan bahwa complete feed fermentasi (perlakuan CF2) menghasilkan nilai serat kasar tercerna secara in vivo yang terbaik dibanding dengan perlakuan $\mathrm{CF} 0$ dan CF1. Secara umum pemberian complete feed berbahan baku utama pod kakao tidak mempengaruhi konsumsi serta $\mathrm{PBBH}$ domba jantan lokal yang sedang tumbuh.

\section{Daftar Pustaka}

Alemawor, F., V. P. Dzogbefia, E. O. K. Oddoye and J. H. Oldham. 2009. Effect of Pleurotus ostreatus fermentation on cocoa pod husk composition: Influence of fermentation period and $\mathrm{Mn}^{2+}$ supplementation on the fermentation process. Afric. J. Biotechnol. 8: 1950-1958.

Anonimus. 2008. Pemanfaatan Limbah Kulit Buah Kakao sebagai Pakan Kambing. Balai Pengkajian Teknologi Pertanian Sulawesi Selatan (BPTP Sulsel). Makassar.

AOAC. 2005. Official Method of Analysis. Association of Official Analytical Chemists. Maryland.

Budisatria, I. G. S. 2006. Dynamics of small ruminant development in central Java Indonesia. $\mathrm{PhD}$ Thesis Animal Production System Group. Wageningen University. The Netherlands. 144 pp.

Kearl, L. C. 1982. Nutrient Requirement of Ruminants in Developing Countries. International Feedstuffs Institute, Utah Agricultural Experiment Station, Utah State University. Logan. 
Kung, L. 2001. Silage fermentation and additives. In: Direct-fed Microbial, Enzyme and Forage Additive Compendium. Miller Publishing Co., Minnetonka.

Lin, L., X. Kan, H. Yan and D. Wang. 2012. Characterization of extracellular cellulosedegrading enzymes from Bacillus thuringiensis strains. Electron. J. Biotechnol. 15: 1-7.

Mazzafera, P. 2002. Degradation of caffeine by microorganisms and potential use of decaffeinated coffee husk and pulp in animal feeding. Sci. Agric. (Piracicaba, Braz.). 59: 815-821.

Parakkasi, A. 1999. Ilmu Nutrisi dan Makanan Ruminan. Universitas Indonesia Press. Jakarta.

Purbowati, E. 2011. Usaha Penggemukan Domba. Cetakan Ketiga. Penebar Swadaya. Jakarta.

Purbowati, E., C. I. Sutrisno, E. Baliarti, S. P. S. Budhi, W. Lestariana, E. Rianto, dan Kholidin. 2009. Penampilan produksi domba lokal jantan dengan pakan komplit dari berbagai limbah pertanian dan agroindustri. Proseding Seminar Nasional Kebangkitan Peternakan. Semarang.

Ranjhan, S. K. 1981. Animal Nutrition in The Tropics. Vicas Publishing House PVT Ltd. New Delhi.

Ratnakomala, S., R. Ridwan, G. Kartina, dan Y. Widyastuti. 2006. Pengaruh inokulum Lactobacillus plantarum 1A-2 dan 1BL-2 terhadap kualitas silase rumput gajah (Pennisetum purpureum). Biodiversitas 7: 131-134.
Sobamiwa, O. 1993. Use of cocoa-pod husk in poultry feeds: a particular reference to the nigerian situation. De Lafforest J. (ed.). Proceedings of $11^{\text {th }}$ International Cocoa Research Conference, Yamoussoukro Cote D’Ivoire, 18-24 July 1993.

Soedjana, T. D. 2005. Accessibility to small ruminants input and output markets in Indonesia. Jurnal Litbang Pertanian 24: $137-$ 142.

Sofyan, O., A., D. Irfan, dan Surisdiarto. 2001. Perubahan bahan organik dan protein pada fermentasi campuran onggok dan kotoran ayam. Jurnal Ilmu-ilmu Hayati 13: 1-7.

Steel, R. G. D. dan J. H. Torrie. 1993. Prisip dan Prosedur Statistika, Suatu Pendekatan Biometrik. Terjemahan Bambang Sumantri. Gramedia Pustaka Utama, Jakarta.

Tillman, A. D., H. Hartadi, S. Reksohadiprodjo, S. Prawirokusumo, dan S. Lebdosoekojo. 1991. Ilmu Makanan Ternak Dasar. Gadjah Mada University Press, Yogyakarta.

Utomo, R. 2012. Evaluasi Pakan dengan Metode Noninvasif. PT Citra Aji Parama. Yogyakarta.

Wulandari, S. 2013. Pengaruh fermentasi pod kakao dengan inokulum mikrobia terhadap komposisi serat dan degradasi theobromin serta karakteristik isolat bakteri pod kakao terfermentasi. Unpublish.

Zain, M. 2009. Substitusi rumput lapangan dengan kulit buah coklat amoniasi dalam ransum domba lokal. Media Peternakan 32: 47-52. 